\title{
Combination Impacts of Irrigation Regimes and N\&K-Humate Rates on Sunflower Productivity and Water Use Efficiency in Sandy Soil.
}

\author{
H. M. A . El-Kotb* and T.I. Borham** \\ "Soil, Water and Environment Research Institute, A.R.C. and \\ ${ }^{* *}$ Soil Science Department, Faculty of Agriculture, Cairo \\ University, Giza, Egypt.
}

\begin{abstract}
7 WO field experiments were carried out under sprinkler irrigation system at the agricultural research station (ARC), Ismailia Governorate, Egypt in two successive summer seasons (2009 and 2010 ) to study the combination effects of irrigation regimes and N\&Khumate rates on some soil properties, yield quantity, yield components, oil yield, crop water requirements as well as nitrogen use efficiency (NUE) and water use efficiency (WUE) of sunflower crop in sandy soil. A split- plot design with four replications was used. Two irrigation regimes $(25 \%$ from the available soil moisture depletion (ASMD) and 50\% ASMD) and four levels of N\&K-humate combined $\left(\mathrm{F}_{0}\right.$ : control treatment, $\mathrm{F}_{1}: 15 \mathrm{~kg} \mathrm{~N}+2.0 \mathrm{~kg}$ k-humate $/$ fed, $\mathrm{F}_{2}: 30 \mathrm{~kg}$ $\mathrm{N}+4.0 \mathrm{~kg}$ k-humate /fed, $\mathrm{F}_{3}: 45 \mathrm{~kg} \mathrm{~N}+6.0 \mathrm{~kg} \mathrm{k}$-humate /fed). The results indicated that the application rates of $\mathrm{N} \& \mathrm{~K}$-humate fertilizers and irrigation scheduling treatments significantly affected soil hydrophysics properties, yield and yield components. Therefore, an increase in total porosity (TP), field capacity (FC) and wilting point (WP), meanwhile, small decreased in soil bulk density and hydraulic conductivity were obtained. The average values of actual evapotranspiration (ETa) were 383.6, 362.6, 352.3 and $330.2 \mathrm{~mm}$, for $25 \%$ ASMD irrigation treatments, respectively. Meanwhile those were 321.6, 310.2, 301.4 and $295.9 \mathrm{~mm}$ for 50\% ASMD irrigation treatments, respectively. Also the chosen treatments were affected on seed yield and yield components. The highest averages of plant height, head diameter, head weight, seed weight/head and 100 seed weight, seeds yield/fed and seed oil/fed, in the two seasons were obtained from the highest application level of N\&K-humate fertilizers and under the irrigation regime of $25 \%$ ASMD. The highest value of WUE was obtained under the highest level of N\&K-humate $\left(\mathrm{F}_{3}\right)$ and at $25 \%$ ASMD irrigation treatment. On the other hand, the highest value of NUE was obtained under the lowest level of N\&K-humate $\left(F_{1}\right)$ and at $25 \%$ ASMD irrigation treatment.
\end{abstract}

Keywords: Sunflower yield, N\&K-humate, Irrigation scheduling, Water requirements and water use efficiency.

Sunflower (Helianthus annuus L.) crop is considered to be one of the most promising oil crops that can meet the oil needs because it is characterized with 
high unsaturated fatty acids and vitamin E content. Sunflower is the fourth oil crop grown worldwide (Fagundes et al., 2007). In Egypt, there is a big shortage in edible vegetable oil for many years due to fluctuations in the production of oil seeds. The cultivated area of sunflower in Egypt is limited in Nile Valley and the delta due to the competition with the other important summer crops. In Egypt, the sunflower is adapted to different types of soils and climatic conditions. This wide adaptability led to the fact that sunflower can be grown in less productive soils, particularly, in the newly reclaimed soil in the desert area, which represented about $96 \%$ of total Egypt area. Moreover, due to the sunflower ability to tolerate short periods of water deficient the potentiality of sunflower to be an important crop in semi-arid environments under limited irrigation. Sunflower is categorized as a low to medium drought sensitive crop (Tolga and Lokman, 2003 and Turhan \& Baser, 2004).

As reported by Karam (1978) the increase in the irrigation regimes reduced plant height, head diameter, seed yield, seed index, seed oil content. In contrast, Anwar et al. (1995) stated that all the yield components were affected by the number of irrigations, as the number of irrigations increased; plant height, head diameter, 1000-seed weight and stalk yield were increased. Flagella et al. (2002) and Ashoub et al. (2003) reported that increasing irrigation regimes lead to decrease plant height, head diameter and 100 seed weight. Incontrast, Ghazy and Abu Ghazala (1999) found that seed and oil yields, seed oil content (\%) and WUE increase in proportion to the increase in the amount of irrigation water given to sunflower. Ashoub et al. (2003) and El-Hafez et al. (2002) reported that increase in seed yield of sunflower depended on hybrids and irrigations regimes. Kazi et al. (2002) found that oil content of sunflower seeds was increased by increasing irrigation water, while Erdemoglu et al. (2003) they observed that oil content did not change significantly by increasing irrigation water. Şandor Maria et al. (2011) indicated that irrigation water use efficiency (IWUE) was calculated as report between yield grain obtained using the irrigation and the irrigation rate. The value of the IWUE was $5.03 \mathrm{~kg}$ yield grain $/ \mathrm{mm}$.

Erdem et al. (2005a) showed that irrigations were started when crop water stress index values reached $0.2,0.4,0.6,0.8$ and 1.0 (non-irrigated). They found that the total irrigation water amounts of T $0.2, \mathrm{~T} 0.4, \mathrm{~T} 0.6$ and $\mathrm{T} 0.8$ treatments were $679,584,470$ and $227 \mathrm{~mm}$, respectively.

$\mathrm{N}$ fertilizer application can guarantee the high yield of crop; it is a general method to improve the yield of crop. Significant responses of seed oil yield to increased levels of $\mathrm{N}, \mathrm{P}$ and $\mathrm{K}$ fertilizers have been observed by several investigators (Abu Ghazala et al., 2001 and Zhang et al., 2010). However, Kene et al. (1992) found that seed oil percentage was not affected by $\mathrm{N}$ or P levels while El-Kalla et al. (1998) found that it decreased with increased $\mathrm{N}$ level.

Large nitrogen supply increases the amount of seed oil per plant and depresses seed oil concentration (Steer et al., 1984). The latter effect results from the dilution of oil in heavier seed produced under high nitrogen. Therefore, smaller $\mathrm{N}$

Egypt. J. Soil Sci. 53, No. 1 (2013) 
concentration does not offset the advantage that large $\mathrm{N}$ supply has on seed number and seed weight so that crop oil yield remains positively related to large N supply.

To date, numerous researches have demonstrated conclusively that humic acids (HS) showed significant impacts on the soil structure and plant growth (Fong et al., 2007). HA in proper concentrations can enhance plant and root growth (Bacilio et al., 2003). Several HS have been identified (Islam et al., 2005). In regard to the potential of the HA, continuous development has led to availability of various commercial humic acid based products and they are widely marketed. The HA products are usually available in the form of inexpensive soluble salts, referred to as potassium humate (Fong et al., 2007). Potassium humate causes an increase in crop quality and tolerance of plant to drought, saline, cold, diseases and pests stresses (Gadimov et al., 2007).

The present research was aimed to investigate the productivity of sunflower as affected by $\mathrm{N} \& \mathrm{~K}$-humate application rates and irrigation regimes under sprinkler irrigation system on newly reclaimed sandy soils of Ismailia Governorate, Egypt.

\section{Material and Methods}

Two field experiments were conducted during two successive seasons of 2009 and 2010 at the Agricultural research station (ARC), Ismailia Governorate, (30.35 N; $30.26 \mathrm{E} ; 20 \mathrm{~m}$, ASL), Egypt to study the combination effects of irrigation regimes and N\&k-humate rates on sunflower (Helianthus annuus L.) yield, its component, oil yield and water use efficiency grown in sandy soil. The experiment was laid out in split plot design with four replicates. Two irrigation regimes were tested when the sunflower plants consume $25 \%\left(\mathrm{I}_{1}\right)$ and $50 \%\left(\mathrm{I}_{2}\right)$ from the available soil moisture depletion (ASMD). The irrigation treatments under sprinkler irrigation system were assigned to the main plots. Four levels of $\mathrm{N} \& \mathrm{k}$-humate $\left(\mathrm{F}_{0:}\right.$ control, $\mathrm{F}_{1}: 15 \mathrm{~kg} \mathrm{~N}+2.0 \mathrm{~kg}$ k-humate $/ \mathrm{fed}, \mathrm{F}_{2}: 30 \mathrm{~kg} \mathrm{~N}+4.0 \mathrm{~kg}$ $\mathrm{k}$-humate /fed, $\mathrm{F}_{3}: 45 \mathrm{~kg} \mathrm{~N}+6.0 \mathrm{~kg} \mathrm{k}$-humate $/ \mathrm{fed}$ ) were assigned to the subplots. Sowing of sunflower seeds was carried out in hills $20 \mathrm{~cm}$ a part and in rows 60 $\mathrm{cm}$ wide $(35,000$ plants/fed) Irrigation water application was controlled through daily measurements of the soil moisture content in the subsequent soil depths, where it was determined using gravimetric method in order to detect when the soil moisture contents reach to irrigation treatment 25\% ASMD $\left(\mathrm{I}_{1}\right)$ and $50 \%$ $\operatorname{ASMD}\left(\mathrm{I}_{2}\right)$.

In order to determine actual evapotranspiration (ETa), soil moisture contents before and after irrigation was determined using the collected undisturbed soil samples by core Auger from different depths. The values of soil moisture content were determined by a gravimetric methods (Klute 1986).Also values of water use efficiency WUE was determined by dividing seed yield $(\mathrm{Kg} / \mathrm{fed})$ on actual evapotranspiration ETa (m³/fed) according to Giriappa (1983). 
Phosphorous as superphosphate form $\left(15.5 \% \mathrm{P}_{2} \mathrm{O}_{5}\right)$ was applied to the soil two weeks before planting. Potassium in the form of potassium sulphate $(50 \%$ $\mathrm{K}_{2} \mathrm{O}$ ) was applied in two equal doses every two weeks intervals after planting. Nitrogen as ammonium sulphate form $(20.5 \% \mathrm{~N})$ was mixed with k-humate and added in four doses every two weeks intervals starting from plant emergence. Irrigation regimes were starting after planting directly using gravimetric method. The potassium humate component used in this study was as follows: [humic acid $(80 \%)$, potassium $\left(\mathrm{K}_{2} \mathrm{O}\right)(10-12 \%)$ and micronutrients such as zinc, iron, manganese, cupper in chelated form and its concentration was $100 \mathrm{ppm}$ ], were sprayed with the recommended doses after 55 and 75 days from planting.

At harvesting samples of 10 guarded plants from each sub-plot were taken randomly in four replications. The recorded data after harvesting include plant length $(\mathrm{cm})$, head diameter $(\mathrm{cm})$, shoot dry matter $(\mathrm{g} / \mathrm{plant})$, root dry matter (g/plant), biomass dry matter (g/plant), shoot: root ratio, 100 seed weight, seed yield $(\mathrm{kg} / \mathrm{fad})$, oil yield $(\mathrm{kg} / \mathrm{fad})$, seed oil content $(\%)$ and Nitrogen use efficiency (NUE) (kg seed/kg N ).

To determine Oil Percentage (\%): Dried mature of seeds were ground into very fine powder and determined oil \% using Soxhelt apparatus and diethyl ether according to A.O.A.C. (1995).

Nitrogen use efficiency (NUE) was calculated using the formula suggested by Moll et al. (1982) by dividing seed yield (Gw) by nitrogen (N) applied to the soil plus mineral nitrogen in the soil before sowing $(\mathrm{Ns})\{\mathrm{NUE}=\mathrm{Gw} / \mathrm{N}+\mathrm{Ns}\}$.

Undisturbed and disturbed surface $(0-20 \mathrm{~cm})$ and subsurface $(20-40 \mathrm{~cm})$ soil samples were collected before sowing to determine some physical and chemical characteristics of the investigated soil, according to the methods described by Page et al. (1982) and Klute (1986). Table 1 showed some soil physical and chemical characteristics of the experimental site.

\section{Results and Discussion}

\section{Combination impacts of irrigation regimes and $N \& K$-humate rates on \\ 1. Hydrophysical properties of the studied sandy soil}

The changes in the studied hydrophysical properties of the tested sandy soil under different application rates of N\&K- humate after the two growing seasons are presented in Table 2. These data indicate that a negative and positive impacts are noticed on the soil moisture constants with increasing the application rate of N\&K-humate, i.e., the values of soil bulk density and hydraulic conductivity are decreased, but these decreases are not significant for bulk density and significant for hydraulic conductivity, whereas the total porosity, retained moisture at field capacity, values of wilting point and available water percentage are significantly increased with increasing the application rates of N\&K-humate. The reducing soil bulk density values may be related to the increasing the percentage of storage

Egypt. J. Soil Sci. 53, No. 1 (2013) 
pores in the studied soil which can be regarded as an index of improving pore size distribution.

TABLE 1. Some physical and chemical properties of the tested soils.

\begin{tabular}{|c|c|}
\hline Character & Value \\
\hline \multicolumn{2}{|c|}{ Particle size distribution } \\
\hline Clay \% & 1.6 \\
\hline Silt \% & 3.7 \\
\hline sand \% & 94.7 \\
\hline Textural class & Sandy soil \\
\hline $\mathrm{Ca} \mathrm{CO}_{3} \%$ & 0.75 \\
\hline Organic matter $\%$ & 0.75 \\
\hline \multicolumn{2}{|c|}{ Chemical analysis } \\
\hline PH (1: 2.5 suspension) & 7.76 \\
\hline $\mathrm{EC}_{\mathrm{e}}(\mathrm{ds} / \mathrm{m}$, soil paste extract $)$ & 2.50 \\
\hline \multicolumn{2}{|l|}{ Soluble cations (soil paste meq/L): } \\
\hline $\mathrm{Ca}^{+2}$ & 8.4 \\
\hline $\mathrm{Mg}^{+2}$ & 5.7 \\
\hline $\mathrm{Na}^{+}$ & 9.4 \\
\hline $\mathrm{K}^{+}$ & 1.5 \\
\hline \multicolumn{2}{|l|}{ Soluble anions (soil paste meq/L): } \\
\hline $\mathrm{HCO}_{3}^{-}+\mathrm{CO}_{3}^{-2}$ & 13.5 \\
\hline $\mathrm{Cl}^{-}$ & 7.6 \\
\hline $\mathrm{SO}_{4}^{-2}$ & 3.9 \\
\hline Total $\mathrm{N} \%$ & 0.02 \\
\hline KCl-extractable N (ppm) & 31.04 \\
\hline
\end{tabular}

TABLE 2. Effect of different application rates of N\&K- humate on some soil hydrophysical properties.

\begin{tabular}{|c|c|c|c|c|c|c|}
\hline \multirow{2}{*}{ Treatments } & \multicolumn{3}{|c|}{ Soil moisture constants (\% volume ) } & \multicolumn{1}{c|}{$\begin{array}{c}\text { Bulk } \\
\text { density } \\
\text { gm/cm }\end{array}$} & $\begin{array}{c}\text { Hydraulic } \\
\text { conductivit } \\
\text { y cm/hr }\end{array}$ \\
\cline { 2 - 5 } & TP & F.C & W.P & AW & & \\
\hline$F_{0}$ & $34.3 \mathrm{a}$ & $9.1 \mathrm{a}$ & $2.2 \mathrm{a}$ & $6.9 \mathrm{a}$ & $1.68 \mathrm{a}$ & $10.4 \mathrm{a}$ \\
\hline $\mathrm{F}_{1}$ & $35.5 \mathrm{~b}$ & $9.8 \mathrm{~b}$ & $2.5 \mathrm{~b}$ & $7.3 \mathrm{~b}$ & $1.63 \mathrm{a}$ & $9.2 \mathrm{~b}$ \\
\hline $\mathrm{F}_{2}$ & $37.6 \mathrm{c}$ & $10.1 \mathrm{c}$ & $2.6 \mathrm{c}$ & $7.5 \mathrm{~b}$ & $1.61 \mathrm{a}$ & $8.6 \mathrm{c}$ \\
\hline $\mathrm{F}_{3}$ & $39.3 \mathrm{~d}$ & $10.5 \mathrm{~d}$ & $2.7 \mathrm{~d}$ & $7.8 \mathrm{c}$ & $1.58 \mathrm{a}$ & $7.9 \mathrm{~d}$ \\
\hline $\mathrm{LSD}_{0.05}$ & 0.26 & 0.16 & 0.18 & 0.24 & 0.18 & 0.18 \\
\hline
\end{tabular}

$\mathrm{TP}=$ Total porosity $\%, \mathrm{FC}=$ field capacity $\%, \mathrm{WP}=$ wilting point $\%, \mathrm{AW}=$ available water $\%$. 
The pronounced decrease in the values of hydraulic conductivity of the studied sandy soil may be due to decrease of macro pores, and the dominance of meso and micro pores on the expose of the other pore sizes. These results are in agreement with those of Mona et al. (2011). Concerning the changes in the values of field capacity, wilting point and available water content at different applied rates of N\&k-humate, data show that the treated soils with $\mathrm{N} \& \mathrm{~K}$ humate possess relatively high values of over mentioned constants as compared to control. The increasing percentages of available water for treatments $F_{1}, F_{2}$ and $F_{3}$ compared to control $\left(F_{o}\right)$ are recorded to be $5.7 \%, 8.9 \%$ and $13.2 \%$, respectively. These increase may be due to the fact that organic substances (humate) contain pronounced high active organic groups that encourage the water molecules to be chelated. Thus, the N\&k-humate is considered as an organic conditioner that improves the previous soil hydrophysical properties through its ability to absorb water and swelling leading to pronounced effect of changing pore size distribution.

\section{Actual evapotranspiration (ETa) of sunflower crop}

Table 3 shows the mean values of actual evapotranspiration $\left(\mathrm{ET}_{\mathrm{a}}\right)$ of sunflower crop during the two growing seasons, as a function of irrigation scheduling treatments. The mean values of $\mathrm{ET}_{\mathrm{a}}$ are 357.2 and $307.3 \mathrm{~mm}$, for $25 \%$ and $50 \%$ ASMD treatment respectively. Results in Table 3 show the values of seasonal consumptive use (actual evapotranspiration) (ET $\mathrm{ET}_{\mathrm{a}}$ of sunflower crop, as a function of irrigation scheduling treatments. The $\mathrm{ET}_{\mathrm{a}}$ values are 383.6, 362.6, 352.3 and 330.2 $\mathrm{mm}$, for 25\% ASMD treatment respectively. Meanwhile, those are 321.6, 310.2, 301.4 and $295.9 \mathrm{~mm}$ for 50\% ASMD irrigation treatment, respectively. This reveal that irrigation at $25 \%$ ASMD has the highest values of seasonal $\mathrm{ET}_{\mathrm{a}}$ whereas, the lowest $\mathrm{ET}_{\mathrm{a}}$ values, are resulted from irrigation at 50\% ASMD regime. These results may be attributed to that irrigation at 25\% ASMD (frequent irrigation) increased the amount of available soil moisture in the root zone of sunflower plants, which led to visible increase in the transpiration process from sunflower shoots and to the increase of evaporation from the soil surface. On the other hand, the results indicate also that the increasing of application rate of N\&K - humus resulted in an observed decrease in the actual evapotranspiration of sunflower crop. Therefore, the highest value of $\mathrm{ET}_{\mathrm{a}}$ is recorded for the control treatments $\left(\mathrm{F}_{\mathrm{o}}\right)$ fallowed by $\mathrm{F}_{1}$ and $\mathrm{F}_{2}$ then $\mathrm{F}_{3}$ which recorded the lowest value. This may be due to the increasing water holding capacity of the sandy soil as a result for adding humus organic materials to the soil.

On the other hand, data listed in Table 3 also indicate that the monthly ETa are started with low values during June, thereafter, increased during July and reached its maximum values during August then it declined again during September (harvesting month). Such findings may be attributed to most of water losses during June are caused by evaporation from the soil (germination and seedling stages) as the roots of sunflower are still very small. Thereafter, as the plant cover increase (vegetative growth) the monthly ETa increased reaching its peak at flowering and seed filling stages, as the roots and shoots reaching to the maximum growth. The values of ETa re-decreased during September (maturity stage) as a result of the drying of lower leaves and to the low transpiration rate.

Egypt. J. Soil Sci. 53, No. 1 (2013) 
TABLE 3. The average values of monthly actual evapotranspiration (ETa) of sunflower crop under different application rates of $N \& K$ humate.

\begin{tabular}{|c|c|c|c|c|c|}
\hline \multirow{2}{*}{$\begin{array}{l}\text { N\&K humate } \\
\text { treatment }\end{array}$} & \multicolumn{5}{|c|}{ ETa $\mathrm{mm} / \mathrm{month}$ for the irrigation regime at $25 \%$ ASMD } \\
\hline & May & June & July & August & Total \\
\hline $\mathrm{F}_{0}$ & 50.2 & 129.6 & 174.8 & 29.1 & 383.6 \\
\hline $\mathrm{F}_{1}$ & 47.4 & 122.5 & 165.2 & 27.5 & 362.6 \\
\hline $\mathrm{F}_{2}$ & 46.1 & 119.1 & 160.5 & 26.7 & 352.3 \\
\hline $\mathrm{F}_{3}$ & 44.3 & 114.5 & 147.0 & 24.4 & 330.2 \\
\hline Mean & & & & & 357.2 \\
\hline \multirow{2}{*}{$\begin{array}{c}\text { N\&K humate } \\
\text { treatment }\end{array}$} & \multicolumn{5}{|c|}{ ETa $\mathbf{m m} /$ month for the irrigation regime at $50 \%$ ASMD } \\
\hline & May & June & July & August & Total \\
\hline$\overline{\overline{\mathrm{F}_{0}}}$ & 24.0 & 109.5 & 1065.5 & 22.6 & 321.6 \\
\hline$F_{1}$ & 22.7 & 103.5 & 161.8 & 22.1 & 310.2 \\
\hline $\mathrm{F}_{2}$ & 22.1 & 100.5 & 157.3 & 21.5 & 301.4 \\
\hline $\mathrm{F}_{3}$ & 21.2 & 96.7 & 156.6 & 21.4 & 295.9 \\
\hline Mean & & & & & 307.3 \\
\hline
\end{tabular}

\section{Plant growth}

Generally, plant growth is significantly differing according to different treatments due to the application rates of (N\&k-humate). The results in Table 4 reveal that the averages of plant length (PL), head diameter (HD), seed weight (SW), 100-seed weight (100-SW), shoot dry matter (SDM), root dry matter (RDM), and biomass dry matter (BDM) per plant are significantly increased as the N\&k-humate rates increased.

The highest application rate of $\mathrm{N} \& \mathrm{k}$-humate $\left(\mathrm{F}_{3}\right)$ give the highest average values of sunflower growth parameters. Comparing to the control treatment $\left(\mathrm{F}_{0}\right)$, the percent of increments for the highest rate $\left(\mathrm{F}_{3}\right)$ are $34.87 \%, 54.59 \%, 53.64 \%, 54.52 \%, 65.15 \%$, $30.74 \%$ and $47.03 \%$ for the following growth parameters PL, HD, SW, 100-SW, SDM, RDM and BDM per plant, respectively. The increment percent of shoot/root ratio are increased by $25.26 \%, 26.84 \%$ and $29.47 \%$ for $\mathrm{F}_{1}, \mathrm{~F} 2$ and $\mathrm{F}_{3}$ treatments, respectively compared to control. The increase in these parameters with the increasing of N\&k-humate rates may be due to the role of nitrogen in activating the growth and yield components and to the role of k-humate in enhancing fertility and physiochemical soil properties. Similar results were obtained by Mojiri and Arzani (2003), Killi (2004) and Osman \& Awed (2010).

Irrespective of fertilizer treatments, plant growth parameters are significantly differing due to irrigation regime treatments. Table 4 shows that the averages of plant length (PL), head diameter (HD), seed weight (SW), 100-seed weight (100-SW), shoot dry matter (SDM), root dry matter (RDM) and biomass dry matter (BDM) per plant are decreased as irrigation regimes increased from $25 \%$ $\operatorname{ASMD}\left(\mathrm{I}_{1}\right)$ to $50 \% \operatorname{ASMD}\left(\mathrm{I}_{2}\right)$. 


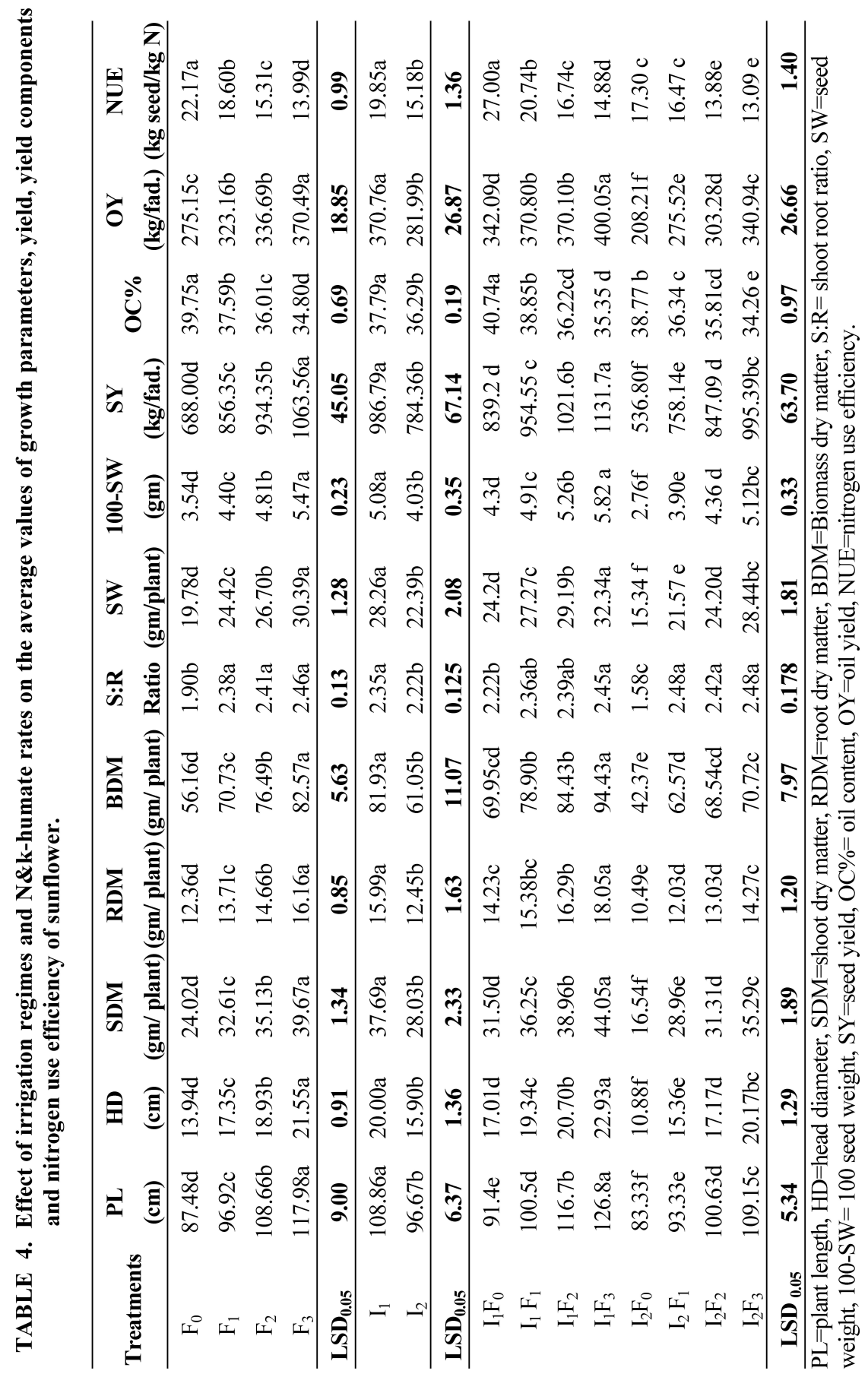

Egypt. J. Soil Sci. 53, No. 1 (2013) 
The percentages of decrements are $11.2 \%, 20.5 \%, 20.8 \%, 20.7 \%, 25.7 \%$, $22.1 \%$ and $25.5 \%$ for PL, HD, SW, 100-SW, SDM, RDM and BDM per plant, respectively. As well as, shoot / root ratio, are decreased as irrigation regime increase from $25 \%$ ASMD to $50 \%$ ASMD $\left(I_{2}\right)$. This may be refer to the effect of water deficit, which in turn reduced plant growth and all yield components (Abdou et al.,2011).

Data presented in Table 4 show that plant length (PL), head diameter (HD), seed weight (SW), 100-seed weight (100-SW), shoot dry matter (SDM), root dry matter $(\mathrm{RDM})$, and biomass dry matter $(\mathrm{BDM})$ per plant are significantly affected by the interaction between irrigation regimes and NK- humate fertilizations rates.

In general, plant growth is markedly affected by N\&k-humate application but the magnitude of response varied widely within irrigation regimes. The lowest values of PL (93.33 cm), HD (15.36 cm), SW (21.57 g) 100-SW (3.90 g), SDM $(28.96 \mathrm{~g}), \mathrm{RDM}(12.03 \mathrm{~g})$ and BDM $(62.57 \mathrm{~g})$ per plant are obtained from $50 \%$ ASMD with the lowest rates of $\mathrm{N} \& \mathrm{k}$-humate rate $\left(\mathrm{F}_{1}\right)$, i.e., under $\mathrm{I}_{2} \mathrm{~F}_{1}$ treatment, while, the highest values of PL $(126.8 \mathrm{~cm}), \mathrm{HD}(22.93 \mathrm{~cm}), \mathrm{SW}(32.34 \mathrm{~g})$, 100-SW (5.82 g), SDM (44.05 g), RDM (18.05 g) and BDM (94.43 g) per plant are obtained from $25 \%$ ASMD $\left(\mathrm{I}_{1}\right)$ with the highest rate of N\&k-humate $\left(\mathrm{F}_{3}\right)$, i.e., $\mathrm{I}_{1} \mathrm{~F}_{3}$ treatment. Vivek et al. (1994) obtained similar results quoting that mean yield of sunflower increased with increasing levels of irrigation and nitrogen fertilizer. Khaliq and Cheema (2005) reported that plant growth and total dry matter production varied with irrigation and nitrogen application rates. Viveck et al. (1994) also reported that substantial yield increase through $\mathrm{N}$ fertilization and the magnitude of the response was dependent on the moisture supply.

\section{Yield, oil content and nitrogen use efficiency}

It is evident from Table 4 that $N \& \mathrm{~K}$ humate treatments have significant impact on the seed yield (SY), oil yield (OY), oil content (OC) and nitrogen use efficiency (NUE). The positive response are observed on seed and oil yield while, oil content and nitrogen use efficiency recorded the negative response. Seed and oil yield recorded increments by $(24.50 \%, 35.81 \%$ and $54.59 \%)$ and $(17.45 \%, 22.37 \%$ and $34.65 \%$ ) for $\mathrm{F}_{1}, \mathrm{~F}_{2}$ and $\mathrm{F}_{3}$, respectively compared to control treatment. On the other hand, oil content and nitrogen use efficiency recorded decrements by $(3.48 \%, 8.01 \%$ and $14.22 \%)$ and $(9.44 \%, 32.95 \%$ and $58.47 \%)$ for $\mathrm{F}_{1}, \mathrm{~F}_{2}$ and $\mathrm{F}_{3}$ respectively compared to control treatment. Such results may be due to the adverse effect of nitrogen on oil content, is offset by an increase in protein content. Protein formation competes more strongly for photosynthesis, as a result, less of the latter are available for fat synthesis and nitrogen depressed the seed oil content. Large nitrogen supply increases the amount of seed oil per plant and depresses seed oil concentration (Steer et al., 1984). This may be attributed to the dilution of oil in heavier seed produced under high nitrogen. Therefore, smaller $\mathrm{N}$ concentration does not offset the advantage that large $\mathrm{N}$ supply has on seed number and seed weight so that crop oil yield remains positively related to large $\mathrm{N}$ supply. These results are agreement with those of Khaliq (2004) and Nasem el al. (2012) they reported that with increasing $\mathrm{N}$ rates, there were an increments in the total dry matter (TDM), grain yield and yield components, while the oil content was negatively affected. 
Data recorded in Table 4 show the averages of seed yield, oil yield, oil content and nitrogen use efficiency which significantly differ due to impact of irrigation regime treatments, whereas irrigation at $25 \%$ ASMD always gives the highest averages, in contrast, the lowest ones are detected from irrigation at 50\% ASMD. It is obvious that increasing irrigation regimes from $25 \%$ to $50 \%$ ASMD significantly decreased seed yield, oil yield, oil content and nitrogen use efficiency by $20.5 \%, 23.9 \%, 4.0 \%$ and $23.5 \%$, respectively. These results may refered to the effect of water deficit, resulted from irrigation at (50\% ASMD). The results are agreement with the finding of El-Hafez et al. (2002) and Ashoub et al. (2003).

It is evident from Table 4 that the interaction affects of N\&k-humate and irrigation regimes have a highly significant effect on seed yield (SY), oil yield (OY), oil content (OC) and nitrogen use efficiency (NUE). In contrast, oil content and nitrogen use efficiency recorded the negative response for all N\&k-humate rates at both $25 \%$ and $50 \%$ ASMD regimes.

As regard to the interaction of the irrigation regimes and N\&k-humate fertilization rates, the (F3 I1) treatment produced high seed and oil yield compared to (F3 I2) treatment. This may be related to low water availability under (F3 I2) treatment. On the other side, the response of sunflower plants for nitrogen fertilizer mainly related to irrigation regimes, where plant growth, yield and yield components are decreased due to increase of irrigation regimes from $25 \%$ to $50 \%$ ASMD which decreased amount of available water availability for plants. These results were agreement with Unger (1990) which reported that fertilizer requirements for sunflower rise with increased irrigation because of the high yields obtained.

\section{Water use efficiency of seeds and oil yield}

Data listed in Table 5 indicate that irrigation at 25\% ASMD lead to high values of WUE ,that are $0.52,0.63,0.69$ and $0.82 \mathrm{~kg}$ seeds $/ \mathrm{m}^{3}$ water for the treatments $\mathrm{Fo}, \mathrm{F}_{1}, \mathrm{~F}_{2}$ and $\mathrm{F}_{3}$, respectively. Meanwhile, the WUE values of $50 \%$ ASMD reached $0.40,0.58,0.67$ and $0.80 \mathrm{~kg}$ seeds $/ \mathrm{m}^{3}$ for the same treatments, respectively. These results indicate that irrigation at $25 \%$ ASMD in sandy soil increase the availability of water to consume by sunflower plants, consequently this was reflected on the seed yield. In contrast, sunflower plants that irrigated at 50\% ASMD are suffer from water deficit so, these plants consume more of energy to absorb water, which reflected negatively on the seed yield of the cultivated crop. These results are agreement with Ghazy and Abu Ghazala (1999).

Data also, indicate that increasing application rate of N\&K-Humate resulted in an increase of WUE of sunflower crops. This may be attributed to the increase of the seed yield and the decrease in the values of actual evapotranspiration resulted from improving water holding capacity of the sandy soil.

Egypt. J. Soil Sci. 53, No. 1 (2013) 
Data listed in Table 5 indicate that the WUE values of oil yield take the same trend of WUE of seed yield, as the irrigation at 25\% ASMD give high values compared with 50\% ASMD for N\&k-humate treatments. The data indicate that increasing of application rate of N\&K-humate resulted in an increase in oil WUE of sunflower crop. This may due to the visible increase in the oil yield and the decrease of actual evapotranspiration resulted from improving physical and chemical properties of sandy soil.

TABLE 5. The average values of seed and oil water use efficiencies of sunflower crop.

\begin{tabular}{|c|c|c|c|c|c|c|c|c|c|c|}
\hline \multirow[b]{2}{*}{$\begin{array}{c}\text { N\& K- } \\
\text { humate } \\
\text { treatments }\end{array}$} & \multicolumn{5}{|c|}{$25 \%$ ASMD } & \multicolumn{5}{|c|}{ 50\% ASMD } \\
\hline & $\begin{array}{c}\text { Seed } \\
\text { yield } \\
\text { Kg/fed }\end{array}$ & $\begin{array}{c}\text { Oil } \\
\text { yield } \\
\text { Kg/fed }\end{array}$ & $\begin{array}{c}\text { ETa } \\
\mathbf{m}^{\mathbf{3}}\end{array}$ & $\begin{array}{l}\text { Seed } \\
\text { WUE } \\
\mathrm{kg} / \mathrm{m}^{3}\end{array}$ & $\begin{array}{c}\text { Oil } \\
\text { WUE } \\
\text { kg/m }\end{array}$ & $\begin{array}{c}\text { Yield } \\
\text { Kg/fed }\end{array}$ & $\begin{array}{c}\text { Oil } \\
\text { yield } \\
\text { Kg/fed }\end{array}$ & $\begin{array}{c}\text { ETa } \\
\mathbf{m}^{\mathbf{3}}\end{array}$ & $\begin{array}{c}\text { Seed } \\
\text { WUE } \\
\text { kg/m } \mathbf{m}^{3}\end{array}$ & $\begin{array}{c}\text { Oil } \\
\text { WUE } \\
\text { kg/m }\end{array}$ \\
\hline $\mathrm{F}_{\mathrm{o}}$ & 839.2 & 342.1 & 1611.1 & 0.52 & 0.21 & 536.8 & 208.2 & 1350.9 & 0.40 & 0.15 \\
\hline $\mathrm{F}_{1}$ & 954.6 & 370.8 & 1522.9 & 0.63 & 0.24 & 758.1 & 275.5 & 1302.6 & 0.58 & 0.21 \\
\hline $\mathrm{F}_{2}$ & 1021.7 & 370.1 & 1479.8 & 0.69 & 0.25 & 847.1 & 303.3 & 1265.9 & 0.67 & 0.24 \\
\hline $\mathrm{F}_{3}$ & 1131.7 & 400.1 & 1386.7 & 0.82 & 0.29 & 995.4 & 340.9 & 1242.8 & 0.80 & 0.27 \\
\hline Mean & 986.8 & 370.8 & 1500.1 & 0.66 & 0.25 & 784.4 & 282.0 & 1290.5 & 0.61 & 0.22 \\
\hline $\mathrm{LSD}_{0.05}$ & & & 74.4 & 0.028 & 0.0113 & & & 21.6 & 0.026 & 0.0112 \\
\hline
\end{tabular}

Results in Table 5 indicate that there are positive significant effects for N\&K humate rates on seed and oil yields of sunflower, where the yields of seed and oil as well as seed and oil WUE increase as N\&K humate rates increased. Meanwhile ETa values decrease with increasing $N \& K$ humate rates. This may be due to increase of water holding capacity and encouraging soil aggregation occur due to the presence of humates.

\section{References}

A.O.A.C. (1995) Association of official Analytical Chemists. "Official Methods of Analysis", $16^{\text {th }}$ ed., AOAC International, Washington, D.C. USA.

Abu-Ghazala, M.E., Table, M.A., El-Essawy, L.I. and Awad, M.M.M. (2001) Evaluation of some sunflower hybrids under different levels of nitrogen fertilization. J. Agric. Res. Tanta Univ. 27(1).

Abdou, S. M. M., Abd El- Latif, K.M., Farrag, R. M. F. and Yousef, K. M. R. (2011) Response of Sunflower Yield and Water Relations to Sowing Dates. Advances in Applied Science Research 2 (3):141-150. 
Anwar, M., Rehman, S., Khan, S. and Quarishi, Z. (1995) Response of sunflower varieties to different irrigation regimes during Kharif season in Peshawar Valley. Sarhad J. Agri. 11: 273-278.

Ashoub, M.A., Abdel-Aziz, I.M.A., Shahin, M.M. and Gohar, M.N. (2003) Impact of irrigation and magnesium fertilization on yield, yield components and chemical contents of sunflower. Arab Universities J. Agric. Sci. 11: 191-204.

Bacilio, M., Vazquez, P. and Bashan, Y. (2003) Alleviation of noxious effects of cattle ranch composts on wheat seed germination by inoculation with Azospirillum spp. Biol. Fertil. Soils 38: 261-266.

El-Hafez, S.A.A., El-Sabbagh, A.A., El-Bably, A.Z. and Abou-El, A. (2002) Evaluation of sprinkler irrigated sunflower in North Delta, Egypt. Alexandria J. Agric. Res. 47: 147-152.

El-Kalla, S.E., Sharief, A.E., Ghoniema and El Saidy, Amal A. (1998) Response of some sunflower hybrids to NPK fertilization rates and yield analysis. Proc. of $8^{\text {th }}$ Conf. Agron. Suez Canal University, Ismailia, Egypt, 28-29 Nov.,1998, pp. 535-543.

Erdem, T., Erdem, Y. Orta, A.H. and Okursoy, H. (2005a) Use of a crop water stress index for scheduling the irrigation of sunflower (Helianthus annuus L.). Turk. J. Agric. 29: 1-10.

Erdemoglu, N., Kusmenoglu, S. and Yenice, N. (2003) Effect of irrigation on the oil content and fatty acid composition of some sunflower seeds. Chem. Nat. Comp. 39: 1-4.

Fagundes, J., Santiago, D., Mello, G., deBellé, A. M. and Streck, N. A. (2007) Growth, development and delay of leaf senescence in pot-grown sunflower (Helianthus annuus L.): sources and rates of nitrogen. Ciência Rural. 37(4), 987

Flagella, Z., Rotunno, T., Tarantino, E., Caterina, R., Caro, A., Di Caterina, R., Di Caterina, A. and De-Caro, A. (2002) Changes in seed yield and oil fatty acid composition of high oleic sunflower (Helianthus annuus L.) hybrids in relation to the sowing date and the water regime. Eur. J. Agron. 17: 221-230.

Fong, S.S., Seng, L. and Mat, H.B. (2007) Reuse of Nitric Acid in the Oxidative Pretreatment Step for Preparation of Humic Acids from Low Rank Coal of Mukah, Sarawak. J. Braz. Chem. Soc. 18(1): 41-46.

Gadimov, A., Ahmaedova, N. and Alieva, R.C. (2007) Symbiosis nodules bacteria Rhizobiumleguminosarum with Peas (Pisum Sativum) nitrate reductase, salinification and potassium humus. Azarbayjan National Academy of Sciences.

Ghazy, M.A. and Abu Ghazala, M.E. (1999) Intercropping sunflower with soybean under water regime and nitrogen fertilizer levels. J. Agric. Sci. Mansoura Univ. 24(1): 336-323.

Giriappa, S. (1983) "Water Use Efficiency in Agriculture ", Oxford \& IBH Publishing C.O., New Delhi.

Egypt. J. Soil Sci. 53, No. 1 (2013) 
Islam, K.M.S., Schuhmacher, A. and Gropp, J.M. (2005) Humic Acid Substances in AnimalAgriculture. Pakistan Journal of Nutrition 4 (3): 126-134.

Karam, C. (1978) Effect of irrigation regimes on yield components of sunflower. Field Crop Abst. 31, 90

Kazi, B.R., Oad, F.C., Jamro, G.H., Jamali, L.A. and Oad, N.L. (2002) Effect of water stress on the growth, yield and oil content of sunflower. Pak. J. Appl. Sci. 2: 550-552.

Kene, H.K., Thosar, V.R., Vlemale, R.B. and Kale, M.R. (1992) Response of sunflower to spacing and nitrogen-phosphorus fertilization. Journal of Maharashtra Agric. Univ. 17(3): 433- 439.

Khaliq, A. (2004) Irrigation and nitrogen management effects on productivity of hybrid sunflower (Helianthus annuus L.). Ph.D. Thesis, Dept. of Agron., Uni. of Agri., Faisalabad, Pakistan.

Khaliq, A. and Cheema, Z.A. (2005) Influence of irrigation and nitrogen management on some agronomic traits and yield of hybrid sunflower. Int. J. Agric. Bio. 7: 915-919.

Killi, F. (2004) Influence of different nitrogen levels on productivity of oilseed and confection sunflowers (Helianthus annuus L.) under varying plant populations. International J. Agric \& Biology 6 (4): 594-598.

Klute, A. (1986) "Methods of Soil Analysis Part I. Physical and Mineralogical Methods", $2^{\text {nd }}$ ed., Agron. Madison, Wisconsin, U.S.A.

Mojiri, A. and Arzani, A. (2003) Effects of Nitrogen Rate and Plant Density on Yield and Yield Components of Sunflower. J. Sci. and Technol. of Agric. and Natural Resources 7 (2): 115-125.

Moll, R.M., Kamprath, E.J., and Jakson, W.A. (1982) Analysis and interpretation which contribute to efficiency of nitrogen utilization. Agronomy Journal 74: 562-564.

Mona K.M. Abdel-Razek, Nadia M. Hemeid and Habashy R. N. (2011) "Beneficial Effect of Some Organic Soil-Conditioning Agents for Improving Sandy Soil Productivity Under Sprinkler Irrigation System". Australian Journal of Basic and Applied Sciences 5 (12): 12-20.

Nasem, W., Ahmad, A., Hammad, H.M., Chaudhary, H.J. and Munis, M.F.H. (2012) Effect of nitrogen on growth and yield of sunflower under semi-arid conditions. Pakistan Advances in Applied Science Research 2 (3):141-150.

Osman, E.B.A. and. Awed, M. M. M (2010) Response of sunflower (Helianthus annuus L.) to phosphorus and nitrogen fertilization under different plant spacing new valley. Vol. 50 (5): 205-211. Ass. Univ. Bull. Environ. Res. Vol. 13 No. 1, March 2010.

Page, A.L. (1982) "Methods of Soil Analysis Part II Chemical and Microbiological Properties ", $2^{\text {nd }}$ ed. Agron. Madison, Wisconsin, U.S.A. 
Şandor Maria, Domuța Cornel, Borza Ioana, Domuţa Cristian, Brejea Radu and Vuşcan Adrian (2011) Multiannual researches regarding the irrigation influence in sunflower from crişurilor plain". Analele Universităţii din Oradea, Fascicula Protecţia Mediului Vol. XVI.

Steer, B.T., Hocking, P.J. Kortt. A.A., and Roxburgh, C.M. (1984) Nitrogen nutrition of sunflower (Helianthus annuus L.) acquisition and partitioning of dry matter and nitrogen by vegetative organs and their relation ship on seed yield. Field Crop Res. 9(3/4): 219-236.

Tolga, E. and Lokman, D. (2003) Yield response of sunflower to water stress under Tekirdag conditions. Helia 26(38): 149-158.

Turhan, H. and Baser, I. (2004) In vitro and In vivo water stress in sunflower (Helianthus annuus L.). Helia 27(40): 227-236.

Unger, P.W. (1990) Sunflower. In: B.A. Stewart and D.R. Nielson, (Ed.) "Irrigation of Agricultural Crops", pp. 775-91, ASA Monograph No. 30, ASA, CSSA, SSSA, Madison, WI .

Vivek, I., Chakor, S. and Sharma, H.K. (1994) Effect of moisture regimes and nitrogen levels on seed yield of sunflower (Helianthus annuus L.). Indian J. Agron. 39: 142-3.

Zhang, Z. H., Song, H. X., Liu, Q., Rong, X. M., Peng, J. W., Xie, G. X., Zhang, Y. P. and Guan, C. Y. (2010) Nitrogen redistribution characteristics of oilseed rape varieties with different itrogen-use efficiencies during later growth period. Communications in Soil Science and Plant analysis 41: 1693-1706. 


$$
\begin{aligned}
& \text { التاثيرات المتبادلة للرى ومعدلات النيتروجين وهيومات البوتاسيوم }
\end{aligned}
$$

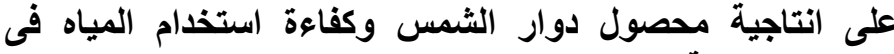

$$
\begin{aligned}
& \text { الار اضى الرملية }
\end{aligned}
$$

أجريت تجربتان حقليتان في المزرعة البحثية التابعة لمحطة بحوث الاسماعيلية

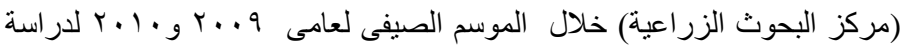

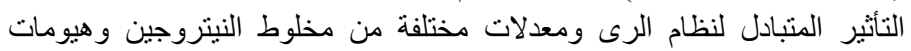

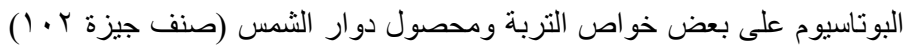

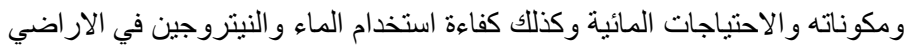

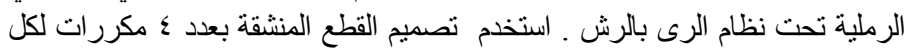

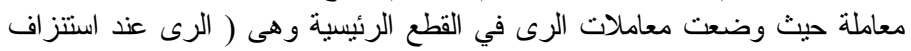

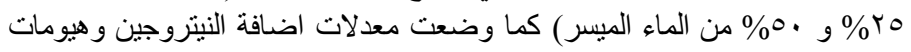

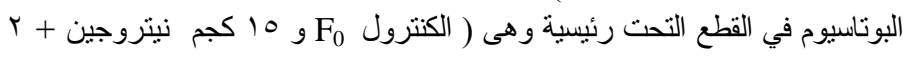

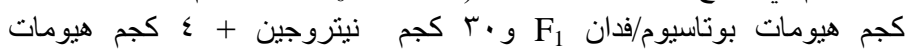

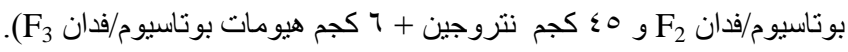
و أوضحت النتائج أن معاملات الرى ومعدلات اضافة النيتروجين وهيومات

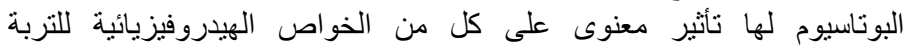

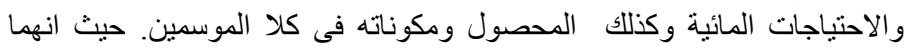

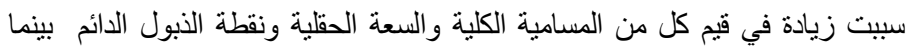

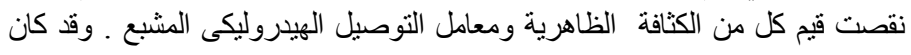

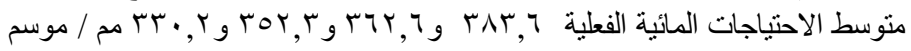

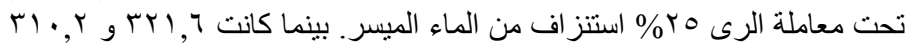

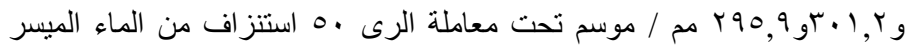

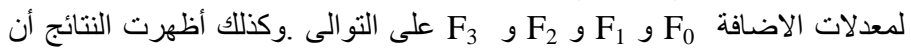

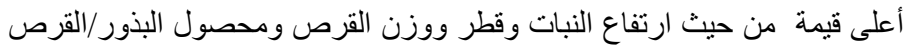

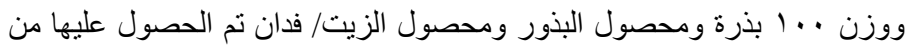

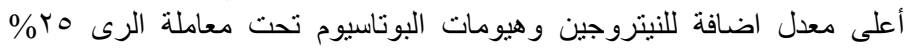

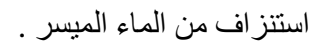

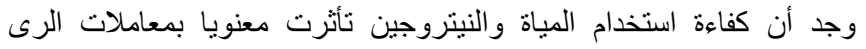

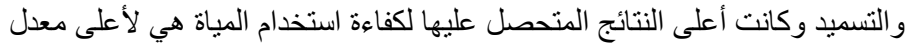

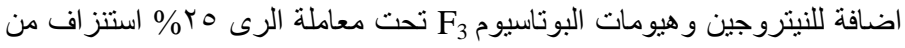

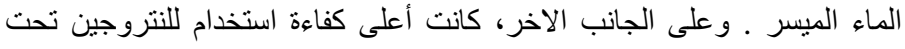

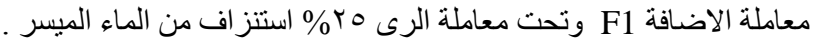

